\title{
HUBUNGAN ASUPAN ISOFLAVON DENGAN KEJADIAN SINDROMA METABOLIK PADA WANITA MENOPAUSE
}

\author{
Ari Yulistianingsih, Apoina Kartini*) \\ Program Studi Ilmu Gizi Fakultas Kedokteran Universitas Diponegoro \\ J1.Dr.Sutomo No.18, Semarang, Telp (024) 8453708, Email : gizifk@ undip.ac.id
}

\begin{abstract}
Background: The metabolic syndrome is defined as a metabolic abnormalities of risk factors for cardiovascular disease, and menopausal is associated with an increase of metabolic syndrome. Dietary isoflavones intake are a phytoestrogen that is cardioprotective factor. The reduction of metabolic markers by isoflavone may be one of the mechanisms by which menopausal women are protected against cardiovascular disease. This study aims to determine the association of dietary isoflavones intake with metabolic syndrome in menopausal women.

Methods: This was a case control study that included 90 menopausal women aged 45 - 65 year old in Saripan sub district of Jepara. Subjects were selected based on inclusion criteria that included 45 subjects for each group. The metabolic syndrome risk score was determined by the presence of at least 3 risk factors such as: waist circumference $\geq 80 \mathrm{~cm}$, blood pressure $\geq 135 / 85 \mathrm{mmHg}$, fasting blood glucose $\geq 100 \mathrm{mg} / \mathrm{dL}$, and triglycerides level $\geq 150 \mathrm{mg} / \mathrm{dL}$. Dietary isoflavones and macronutrients intake data were obtained using Food Frequency Questionnaire (FFQ), while physical activity was obtained using International Physical Activity Questionnaire (IPAQ). Chi square were used for data analysis.

Results: The daily isoflavone intakes by the metabolic syndrome group and the pre syndrome group were 17,8 mg and $44 \mathrm{mg}$. There was an inverse association between dietary isoflavones intake with metabolic syndrome in menopausal women ( $p=0,000 ;$ OR=6,8).

Conclusions: Low dietary isoflavones intake are risk factor for increasing metabolic syndrome in menopausal women with the risk value 6,8 times.
\end{abstract}

Keyword : Dietary isoflavones intake; metabolic syndrome; menopausal women

ABSTRAK

Latar belakang: Sindroma metabolik merupakan kumpulan kelainan metabolik dari faktor risiko penyakit jantung, dan menopause dihubungkan dengan peningkatan kejadian sindroma metabolik. Asupan isoflavon merupakan suatu fitoestrogen yang bersifat kardioprotektif. Penurunan konsentrasi indikator stres metabolik oleh isoflavon dapat menjadi salah satu mekanisme dalam mencegah penyakit jantung pada wanita menopause. Penelitian ini bertujuan untuk mengetahui hubungan asupan isoflavon dengan kejadian sindroma metabolik pada wanita menopause.

Metode: Rancangan penelitian adalah case control yang dilakukan pada 90 wanita menopause usia 45 - 65 tahun di kelurahan Saripan, kabupaten Jepara. Subyek dipilih berdasarkan kriteria inklusi dengan jumlah sampel minimal masing-masing untuk kelompok sebesar 45 subyek. Penentuan sindroma metabolik apabila memiliki $\geq 3$ kriteria sindroma metabolik, yaitu lingkar pinggang $\geq 80 \mathrm{~cm}$; tekanan darah $\geq 135 / 85 \mathrm{mmHg}$; kadar glukosa darah puasa $\geq$ $100 \mathrm{mg} / \mathrm{dL} ; \mathrm{kadar}$ trigliserida $\geq 150 \mathrm{mg} / \mathrm{dL}$. Data asupan isoflavon dan makronutrien diperoleh melalui Food Frequency Questionnaire (FFQ), sedangkan data aktivitas fisik diperoleh melalui International Physical Activity Questionnaire (IPAQ). Analisis data dilakukan dengan menggunakan uji Chi-square.

Hasil: Rata-rata asupan isoflavon pada kelompok sindroma metabolik dan pra sindroma metabolik adalah 17,8 mg/hari dan $44 \mathrm{mg} /$ hari. Terdapat hubungan terbalik antara asupan isoflavon dengan sindroma metabolik pada wanita menopause ( $p=0,000 ; O R=6,8)$.

Kesimpulan: Asupan isoflavon yang kurang merupakan faktor risiko terhadap peningkatan sindroma metabolik pada wanita menopause dengan besar risiko 6,8 kali.

Kata Kunci : Asupan isoflavon; sindroma metabolik; wanita menopause

\section{PENDAHULUAN}

Sindroma metabolik adalah sekumpulan gejala yang disebabkan oleh sekelompok faktor yang saling berhubungan dan dapat meningkatkan risiko penyakit kardiovaskuler dan diabetes mellitus tipe 2.,2,3 Menurut International Diabetes Federation (IDF) dan American Heart Association/National Heart, Lung and Blood Institute (AHA/NHLBI) kriteria sindroma metabolik yaitu apabila seseorang terdapat sedikitnya tiga dari lima komponen, yaitu obesitas sentral, peningkatan tekanan darah, penurunan kadar kolesterol HDL (high-density lipoprotein), peningkatan kadar trigliserida, dan peningkatan glukosa darah puasa. ${ }^{4}$

Suatu penelitian di Jakarta menunjukkan, bahwa secara umum prevalensi sindroma metabolik didefinisikan sebagai kombinasi dari peningkatan

\footnotetext{
${ }^{*}$ Penulis Penanggungjawab
} 
lingkar pinggang dan peningkatan kadar trigliserida serta hipertensi pada usia dewasa, yaitu sebanyak $14,9 \%$. Wanita dewasa mempunyai prevalensi sindroma metabolik lebih tinggi daripada laki-laki. ${ }^{5}$ Di Indonesia, prevalensi sindroma metabolik sebesar $13,13 \% .^{6}$ Provinsi Jawa Tengah memiliki prevalensi hipertensi sebesar 26,4\%, diabetes mellitus sebesar $1,9 \%$, dan penyakit jantung koroner sebesar $1,4 \%$. Prevalensi hipertensi pada wanita sebesar $28,8 \%$ dan laki-laki sebesar 22,8\%.7 Angka prevalensi ini menunjukkan bahwa penyakit kardiovaskuler dan diabetes mellitus merupakan masalah kesehatan yang banyak terjadi di masyarakat, khususnya pada wanita.

Pada tahun 2012, kabupaten Jepara memiliki prevalensi hipertensi sebesar 2,1\%, diabetes mellitus sebesar $0,64 \%$, dan penyakit jantung koroner sebesar $0,03 \% .{ }^{8}$ Berdasarkan kasus yang terdapat di Puskesmas dan rumah sakit di kabupaten Jepara, kasus diabetes mellitus tipe 2 pada tahun 2012 sebesar 252 kasus. ${ }^{9}$ Selain itu, kasus hipertensi terbesar adalah Puskesmas Jepara sebesar 3013 kasus. ${ }^{8}$ Angka ini menunjukkan bahwa masih banyaknya kejadian penyakit degeneratif di kota berkembang, khususnya di Jepara.

Sindroma metabolik merupakan kelainan metabolik yang dapat terjadi pada wanita menopause. Hal ini dapat meningkatkan risiko penyakit kardiovaskuler dan diabetes mellitus tipe 2 yang merupakan penyebab kematian utama pada wanita menopause. ${ }^{10}$ Di Negara berkembang khususnya di Asia, prevalensi diabetes mellitus tipe 2 dan penyakit jantung koroner meningkat dengan tajam. ${ }^{11}$ Sebanyak $10 \%$ wanita premenopause, $41,67 \%$ perimenopause dan $46 \%$ wanita postmenopause menurut kriteria International Diabetes Federation (IDF) diketahui memiliki sindroma metabolik. ${ }^{12}$ Selama menopause, pola sekresi hormon berubah dan terjadi penurunan sekresi estrogen. Perubahan sekresi hormon ini secara bertahap menyebabkan perubahan metabolisme akumulasi lemak dalam jaringan viseral abdomen sehingga menyebabkan obesitas sentral. ${ }^{12,13}$

Isoflavon merupakan suatu fitoestrogen yang dapat berikatan dengan reseptor endogen. Suatu bukti menunjukkan, bahwa peningkatan konsumsi kedelai dapat bersifat kardioprotektif. ${ }^{14,15} \mathrm{Hal}$ ini dapat terjadi karena kemampuan isoflavon yang ditemukan dalam kedelai (genistein, daidzein, dan glicetin) bertindak sebagai peniru estrogen atau modulator reseptor estrogen yang selektif. ${ }^{14}$ Isoflavon sebagian besar ditemukan dalam kedelai dan olahannya. Manfaat kardioprotektif dikaitkan dengan isoflavon karena dalam tubuh bertindak sebagai antioksidan yang menetralisasi radikal bebas penyebab kerusakan oksidatif sel. ${ }^{16}$

Wanita menopause dengan sindroma metabolik yang mengkonsumsi kacang kedelai menunjukkan perbaikan dalam kontrol glikemik dan profil lipid. Selain itu, orang dewasa dengan diabetes mellitus tipe 2 yang mengkonsumsi protein kedelai memiliki manfaat dalam perubahan profil lipid, tetapi tidak pada kontrol glikemik. Mengkonsumsi protein kedelai dan isoflavon dapat meningkatkan fungsi vaskuler. Wanita postmenopause hipertensi yang mengkonsumsi kacang kedelai memiliki perbaikan dalam tekanan darah sebagai penurunan terhadap inflamasi vaskuler. ${ }^{17}$

Selain asupan isoflavon, terdapat variabel lain yang dapat mempengaruhi sindroma metabolik, yaitu diet dan aktivitas fisik. Asupan lemak jenuh yang tinggi dapat meningkatkan kadar trigliserida darah. Sebaliknya, diet tinggi protein nabati dan rendah karbohidrat dapat menurunkan faktor risiko penyakit jantung, yaitu penurunan serum triasilgliserol dan tekanan darah, serta peningkatan kadar kolesterol HDL dan ukuran partikel kolesterol LDL. ${ }^{18,19}$

Modifikasi diet merupakan komponen penting dalam penurunan berat badan. Beberapa penelitian menyebutkan, bahwa diet tinggi protein dan rendah karbohidrat dapat membantu dalam menurunkan massa lemak, khususnya massa lemak abdomen. ${ }^{18}$ Kenaikan berat badan pada orang dewasa berisiko mengalami peningkatan kadar trigliserida. ${ }^{20}$ Suatu studi di Amerika pada 3965 wanita menopause yang berusia 45 - 64 tahun, menunjukkan bahwa obesitas merupakan faktor risiko sindroma metabolik $(\mathrm{OR}=13,01){ }^{21}$ Suatu penelitian menyebutkan, bahwa subyek yang mengkonsumsi diet Mediteranian memiliki penurunan prevalensi sindroma metabolik sebesar $43 \%$. Studi cross-sectional pada 42 wanita menopause dengan sindroma metabolik yang diberi perlakukan diet berbasis protein kedelai atau kacang kedelai menunjukkan penurunan kadar glukosa darah puasa. ${ }^{22}$

Aktivitas fisik diketahui dapat meningkatkan toleransi glukosa, sensitivitas insulin, dan mengurangi risiko penyakit kardiovaskuler. Penurunan jaringan adiposa, khususnya lemak viseral dapat menjadi perantara sensitivitas insulin dalam menurunkan berat badan. Aktivitas fisik teratur diketahui dapat meningkatkan metabolisme insulin pada pasien yang memiliki berat badan berlebih atau obesitas. Aktivitas fisik teratur dan latihan aerobik dengan pembatasan diet diketahui dapat meningkatkan sensitivitas insulin. Resistensi 
insulin berbanding terbalik dengan asupan lemak yang rendah diikuti dengan latihan fisik, tetapi berbanding lurus dengan IMT. ${ }^{22}$

Asupan isoflavon yang kurang, kualitas diet yang buruk, serta aktivitas fisik yang kurang pada wanita menopause merupakan faktor yang dapat meningkatkan risiko penyakit jantung dan diabetes mellitus tipe 2. Namun, penelitian tentang hubungan antara asupan makan, aktivitas fisik, dan komponen sindroma metabolik pada wanita menopause masih terbatas. Penelitian ini bertujuan untuk mengetahui hubungan antara asupan isoflavon dengan kejadian sindroma metabolik pada wanita menopause.

\section{METODE}

Penelitian ini termasuk dalam ruang lingkup keilmuan gizi masyarakat yang dilakukan dengan rancangan case control. Besar sampel minimal masing-masing kelompok berjumlah 45 sampel dihitung dengan menggunakan rumus case control tidak berpasangan. Pemilihan sampel dilakukan dengan cara consecutive sampling. Subyek penelitian adalah anggota posyandu lansia di kelurahan Saripan, Kabupaten Jepara, dengan kriteria inklusi kelompok sindroma metabolik adalah wanita menopause usia 45 - 65 tahun, memiliki $\geq 3$ kriteria sindroma metabolik menurut International Diabetes Federation (IDF) ${ }^{23}$, yaitu lingkar pinggang $\geq 80 \mathrm{~cm}$; tekanan darah $\geq 135 / 85$ $\mathrm{mmHg}$; kadar glukosa darah puasa $\geq 100 \mathrm{mg} / \mathrm{dL}$; kadar trigliserida $\geq 150 \mathrm{mg} / \mathrm{dL}$, tidak merokok dan mengkonsumsi alkohol, serta tidak mempunyai riwayat keluarga dan belum terdiagnosis diabetes mellitus dan hipertensi.

Skrining awal dilakukan pada semua subyek untuk mengetahui subyek mana yang termasuk dalam kelompok pra sindroma metabolik. Pengukuran pada skrining awal meliputi antropometri dan tekanan darah. Pengukuran antropometri meliputi pengukuran berat badan, tinggi badan, dan lingkar pinggang. Pengukuran berat badan menggunakan timbangan digital dengan ketelitian $0,1 \mathrm{~kg}$ dan kapasitas $150 \mathrm{~kg}$, sedangkan pengukuran tinggi badan menggunakan microtoise dengan ketelitian $0,1 \mathrm{~cm}$ dan kapasitas $2 \mathrm{~m}$. Pengukuran lingkar pinggang menggunakan pita ukur dengan ketelitian $0,1 \mathrm{~cm}$ dan kapasitas $150 \mathrm{~cm}$. Pengukuran tekanan darah menggunakan Sphygmomanometer air raksa pada subyek yang tidak melakukan aktivitas fisik berat dan dalam kondisi duduk. Skrining lanjut dilakukan melalui pengambilan darah yang meliputi kadar glukosa darah puasa dan trigliserida untuk mengetahui apakah memenuhi kriteria inklusi kelompok sindroma metabolik.

Data yang dikumpulkan adalah data asupan isoflavon, makronutrien, dan aktivitas fisik. Asupan isoflavon dan makronutrien diperoleh melalui FFQ (Food Frequency Questionnaire) semi kuantitatif. Data ini merupakan jumlah rerata asupan isoflavon dan makronutrien yang terdapat dalam bahan makanan yang dikonsumsi oleh subyek selama 1 bulan terakhir. Asupan isoflavon baik apabila $\geq 22$ $\mathrm{mg} / \mathrm{hr}$; dan kurang apabila $<22 \mathrm{mg} / \mathrm{hr} .{ }^{24}$ Asupan makronutrien dibandingkan dengan kebutuhan energi tiap individu menurut AKG. Asupan karbohidrat, protein, dan lemak dikategorikan tinggi apabila $>65 \%,>10 \%,>25 \%$ dari total kebutuhan energi. ${ }^{25}$ Analisis konsumsi zat gizi menggunakan Nutrisurvey dan tabel kandungan isoflavon pada bahan makanan menurut USDA. ${ }^{26}$ Aktivitas fisik adalah banyaknya energi yang dikeluarkan oleh seseorang untuk melakukan aktivitas fisik seharihari yang diperoleh melalui wawancara menggunakan International Physical Activity Questionnaire (IPAQ). Aktivitas fisik ringan apabila < 600 METs-min/minggu dan sedang apabila $\geq 600$ METs-min/minggu. ${ }^{27}$

Kadar trigliserida dianalisis dengan pemeriksaan laboratorium menggunakan metode CHOD-PAP (Cholesterol Oxidase Para Aminophenazone), sedangkan kadar glukosa darah puasa diperiksa dengan metode GOD-PAP (Glucose Oxidase Para Aminophenazone), di Laboratorium Patra Medica Jepara. Uji normalitas menggunakan Kolmogorov-smirnov dimana jumlah sampel $>50$ orang. Karakteristik subyek dianalisis menggunakan analisis deskriptif. Analisis bivariat untuk mengetahui faktor risiko asupan isoflavon terhadap kejadian sindroma metabolik menggunakan uji Chi-square.

\section{HASIL PENELITIAN \\ Karakteristik Subyek}

Hasil skrining awal yang melibatkan 151 subyek menunjukkan 43 subyek $(28,5 \%)$ mengalami overweight dan 57 subyek $(37,7 \%)$ mengalami obesitas. Karakteristik subyek dapat dilihat pada tabel 1 . 
Tabel 1. Karakteristik subyek berdasarkan nilai median, rerata, dan standar deviasi

\begin{tabular}{lcccc}
\hline \multirow{2}{*}{ Karakteristik } & \multicolumn{2}{c}{ Sindroma Metabolik $(\mathrm{n}=45)$} & \multicolumn{2}{c}{ Pra Sindroma Metabolik (n=45) } \\
\cline { 2 - 5 } & Median & Rerata \pm SD & Median & Rerata \pm SD \\
\hline Umur (tahun) & 56 & $55,4 \pm 6,7$ & 55 & $55 \pm 6,5$ \\
IMT (kg/m²) & 27,82 & $28,3 \pm 2,4$ & 22,03 & $22,1 \pm 2,1$ \\
Lingkar pinggang (cm) & 86 & $86,9 \pm 5,5$ & 73 & $72,6 \pm 4,4$ \\
Tekanan darah, mmHg & & & & \\
\multicolumn{1}{c}{ Sistolik } & 150 & $150,9 \pm 15,0$ & 110 & $114,4 \pm 10,3$ \\
$\quad$ Diastolik & 90 & $92 \pm 5,0$ & 80 & $77,1 \pm 4,6$ \\
Asupan energi (kkal) & 1879,5 & $1777,2 \pm 557,2$ & 1653,3 & $1560,7 \pm 329,4$ \\
Asupan karbohidrat (gr) & 246,2 & $244,9 \pm 94,6$ & 226,9 & $226,6 \pm 58,0$ \\
Asupan protein (gr) & 69,4 & $65,1 \pm 27,3$ & 57,0 & $55,0 \pm 15,0$ \\
Asupan lemak (gr) & 51,2 & $57,8 \pm 24,8$ & 51,4 & $48,2 \pm 13,0$ \\
\hline
\end{tabular}

Rerata umur pada kelompok sindroma metabolik adalah 55,4 $\pm 6,7$ tahun, sedangkan kelompok pra sindroma metabolik $55 \pm 6,5$ tahun. Rerata lingkar pinggang kelompok sindroma metabolik lebih tinggi $(86,9 \pm 5,5) \mathrm{cm}$ dibanding kelompok pra sindroma metabolik $(72,6 \pm 4,4) \mathrm{cm}$. Rerata asupan energi pada kelompok sindroma metabolik lebih tinggi $(1777,2 \pm 557,2) \quad$ kkal dibanding kelompok pra sindroma metabolik $(1560,7 \pm 329,4)$ kkal. Rerata asupan karbohidrat, protein, dan lemak pada kelompok sindroma metabolik lebih tinggi dibanding kelompok pra sindroma metabolik.

Tabel 2. Distribusi Frekuensi Asupan Makronutrien dan Aktivitas Fisik

\begin{tabular}{lcccc}
\hline \multirow{2}{*}{ Karakteristik } & \multicolumn{3}{c}{ Sindroma metabolik $(\mathrm{n}=45)$} & Pra sindroma metabolik $(\mathrm{n}=45)$ \\
\cline { 2 - 5 } & $\mathrm{n}$ & $\%$ & $\mathrm{n}$ & $\%$ \\
\hline Asupan Karbohidrat & 34 & 75,6 & 33 & 73,3 \\
$\quad$ Normal & 11 & 24,4 & 12 & 26,7 \\
$\quad$ Tinggi & & & & \\
Asupan Protein & 39 & 86,7 & 35 & 77,8 \\
$\quad$ Normal & 6 & 13,3 & 10 & 22,2 \\
$\quad$ Tinggi & & & & \\
Asupan Lemak & 14 & 31,1 & 21 & 56,7 \\
$\quad$ Normal & 31 & 68,9 & 24 & 77,8 \\
$\quad$ Tinggi & & & & 22,2 \\
Aktivitas Fisik & 43 & 95,6 & 35 & \\
$\quad$ Ringan & 2 & 4,4 & 10 & \\
$\quad$ Sedang & & & & \\
\hline
\end{tabular}

Pada kelompok sindroma metabolik, asupan karbohidrat tinggi lebih sedikit $(24,4 \%)$ dibanding kelompok pra sindroma metabolik (26,7\%). Asupan protein tinggi pada kelompok pra sindroma metabolik lebih banyak $(22,2 \%)$ dibanding kelompok sindroma metabolik $(13,3 \%)$. Asupan lemak tinggi pada kelompok sindroma metabolik lebih banyak $(68,9 \%)$ dibanding kelompok pra sindroma metabolik $(53,3 \%)$. Aktivitas fisik ringan lebih banyak pada kelompok sindroma metabolik $(95,6 \%)$ dibanding kelompok pra sindroma metabolik $(77,8 \%)$.

Tabel 3. Asupan Isoflavon sebagai Faktor Risiko Kejadian Sindroma Metabolik

\begin{tabular}{|c|c|c|c|c|}
\hline \multirow{2}{*}{ Asupan Isoflavon } & \multicolumn{2}{|c|}{ Sindroma metabolik $(n=45)$} & \multicolumn{2}{|c|}{ Pra sindroma metabolik $(n=45)$} \\
\hline & $n$ & $\%$ & $\mathrm{n}$ & $\%$ \\
\hline Kurang & 34 & 75,6 & 14 & 31,1 \\
\hline Baik & 11 & 24,4 & 31 & 68,9 \\
\hline
\end{tabular}

Tabel 3 menunjukkan, bahwa asupan isoflavon yang kurang pada kelompok sindroma metabolik lebih banyak $(75,6 \%)$ dibanding kelompok pra sindroma metabolik $(31,1 \%)$. Berdasarkan uji Chi-square, asupan isoflavon yang kurang berisiko 6,8 kali untuk terjadinya sindroma metabolik ( $\mathrm{p}=0,000 ; \mathrm{OR}=6,8 ; \mathrm{CI}=2,70-13,70)$.

\section{PEMBAHASAN}

Sindroma metabolik dipengaruhi oleh usia dan jenis kelamin. Wanita menopause memiliki nilai rata-rata yang tinggi pada tekanan darah, lingkar pinggang, kadar glukosa darah puasa, dan 
trigliserida sehingga dapat meningkatkan risiko penyakit jantung dan diabetes mellitus tipe $2 .^{28}$ Menopause merupakan proses penuaan alami yang terjadi pada wanita. Defisiensi hormon estrogen pada menopause mempengaruhi distribusi lemak dalam tubuh. Obesitas sentral dan hipertensi merupakan penyebab utama sindroma metabolik pada wanita menopause.

Salah satu faktor yang mempengaruhi sindroma metabolik adalah diet. Isoflavon sebagian besar terdapat pada kacang-kacangan dan olahannya. Namun, berdasarkan tabel kandungan isoflavon menurut USDA terdapat 22 jenis bahan makanan yang dapat dianalisis kandungan isoflavonnya dalam penelitian ini. Selain itu, penelitian ini menunjukkan perbedaan asupan isoflavon pada wanita menopause antara kelompok sindroma metabolik dan pra sindroma metabolik. Rata-rata asupan isoflavon pada kelompok sindroma metabolik dan pra sindroma metabolik adalah $17,9 \mathrm{mg} /$ hari dan $44,0 \mathrm{mg} /$ hari. Angka ini hampir mendekati angka asupan isoflavon yang biasa dikonsumsi oleh beberapa Negara Asia sebesar 20 - 80 mg/hari. ${ }^{29}$ Rata-rata asupan isoflavon pada wanita menopause di Asia yang tinggi dihubungkan dengan penurunan faktor risiko penyakit jantung pada wanita menopause. ${ }^{30}$ Penelitian yang sama dilakukan oleh Kim Hyun Mi pada wanita menopause di Korea menunjukkan, bahwa asupan isoflavon pada kelompok kasus dan kontrol sebesar 27,99 mg/hari dan 31,64 mg/hari. ${ }^{31}$

Pada penelitian ini, terdapat hubungan yang signifikan antara asupan isoflavon dengan kejadian sindroma metabolik pada wanita menopause $(\mathrm{p}=0,000)$. Subyek dengan asupan isoflavon $<22$ $\mathrm{mg} / \mathrm{hr}$ ditemukan berisiko 6,8 kali lebih besar mengalami sindroma metabolik $(p=0,000)$. Penelitian ini sejalan dengan penelitian An Pan yang menemukan bahwa asupan isoflavon pada protein kedelai merupakan faktor protektif terhadap risiko sindroma metabolik pada wanita $(\mathrm{OR}=$ $0,66) .{ }^{28}$ Asupan isoflavon pada wanita menopause baik apabila $\geq 22 \mathrm{mg} / \mathrm{hr}$; dan kurang apabila $<22$ $\mathrm{mg} / \mathrm{hr} .{ }^{24}$ Pada penelitian ini, sebanyak 34 subyek $(75,6 \%)$ dengan asupan isoflavon yang kurang mengalami sindroma metabolik.

Isoflavon merupakan fitoestrogen yang bertindak sebagai antioksidan dalam tubuh. Isoflavon sebagian besar ditemukan dalam kedelai dan makanan yang terbuat dari olahan kedelai. ${ }^{16}$ Salah satu jenis isoflavon, yaitu genistein pada konsentrasi fisiologis dapat meningkatkan fungsi endotel dan efeknya sebagian besar tergantung pada NO. Stress oksidatif dapat meningkatkan perkembangan disfungsi endotel, kekakuan arteri, dan hipertensi. Disfungsi endotel dapat terjadi pada penderita penyakit jantung. Peningkatan tekanan darah dapat terjadi karena peningkatan stress oksidatif. Isoflavon memiliki pengaruh langsung dalam mengurangi stress oksidatif pada dinding arteri. Kerusakan oksidatif lipoprotein pada dinding arteri dapat meningkatkan aterosklerosis. Protein kedelai dapat menurunkan kolesterol dan trigliserida $>10 \%$ pada individu dengan peningkatan tekanan darah dan kadar trigliserida. ${ }^{32}$

Beberapa mekanisme potensial dapat menjelaskan manfaat isoflavon pada kardiovaskuler. Isoflavon memiliki afinitas untuk reseptor estrogen pada pembuluh darah yang mirip dengan estrogen, dan isoflavon telah terbukti dapat mencapai vasodilatasi yang mirip dengan estradiol pada manusia. Selain peran isoflavon pada stress oksidatif dan resistensi insulin, isoflavon dihubungkan dengan penurunan konsentrasi faktor nekrosis tumor dan CRP pada manusia. Manfaat isoflavon tersebut dapat berkontribusi sebagai faktor protektif terhadap penyakit jantung. ${ }^{33}$

Penelitian in vitro menunjukkan, bahwa beberapa mekanisme langsung oleh kedelai pada kontrol glikemik meliputi penghambatan tirosin kinase, perubahan sejumlah afinitas dan reseptor insulin, fosforilasi intraseluler, dan perubahan transport glukosa. Obesitas merupakan variabel penting dalam metabolisme lemak dan karbohidrat. Beberapa penelitian in vitro menyebutkan bahwa terdapat manfaat kedelai pada diabetes. Isoflavon bertindak sebagai alfa-glukosidase inhibitor yang menghambat uptake brush border glukosa dan memiliki inhibitor tirosin kinase. ${ }^{29}$

Peningkatan kadar trigliserida total dan kolesterol total plasma sering terjadi pada keadaan diabetes mellitus. Insulin mempunyai peran dalam penghambatan hormon sensitif lipase dan pengaktifan lipoprotein lipase (LPL). Dalam keadaan diabetik, mobilisasi asam lemak dari deposit perifer meningkat dan kadar serum trigliserida total meningkat. Penurunan kadar trigliserida dapat disebabkan oleh penurunan berat badan. ${ }^{34}$ Pada subyek obese, protein kedelai dapat menurunkan berat badan dan massa lemak tubuh, serta menurunkan plasma lipid. Mekanisme isoflavon pada kedelai adalah meningkatkan resistensi insulin serta menurunkan lemak tubuh dan kadar lipid darah yang dapat mempengaruhi metabolisme asam lemak dan homeostasis kolesterol. $^{35}$

Selain asupan isoflavon, terdapat variabel lain yang dapat mempengaruhi sindroma metabolik, yaitu asupan makronutrien dan aktivitas fisik. Pada penelitian ini, sebanyak 31 subyek $(68,9 \%)$ dengan 
asupan lemak tinggi mengalami sindroma metabolik. Diet tinggi lemak jenuh dan lemak trans merupakan faktor risiko penyakit jantung. ${ }^{36,37}$ Selain itu, diet tinggi lemak total merupakan faktor risiko obesitas. Oleh karena meningkatnya risiko obesitas, diet tinggi lemak secara tidak langsung dapat meningkatkan risiko diabetes dan peningkatan tekanan darah. Penyebab meningkatnya kadar trigliserida dalam darah adalah overweight, diabetes yang tidak terkontrol, kelebihan asupan lemak, dan kelebihan asupan gula serta pemanis. ${ }^{37}$

Asupan karbohidrat yang tinggi ( $>70 \%$ dari total energi) berhubungan dengan peningkatan IMT, tekanan darah, glukosa darah puasa, kadar trigliserida, dan kolesterol LDL pada wanita. Penelitian International Macronutrients and Blood Pressure (INTERMAP) dan beberapa penelitian lain menunjukkan, bahwa terdapat korelasi negatif antara asupan protein, terutama protein nabati dengan tekanan darah. Diet karbohidrat yang diganti dengan diet protein nabati atau asupan lemak tidak jenuh dapat menurunkan kadar trigliserida darah. ${ }^{38}$

Pada penelitian ini, rerata asupan karbohidrat, protein, dan lemak pada kelompok sindroma metabolik lebih tinggi dibanding kelompok pra sindroma metabolik. Namun, asupan makronutrien yang dikonsumsi oleh kelompok sindroma metabolik masih dalam batas normal. Batasan normal ini hampir mendekati angka asupan karbohidrat, protein, dan lemak pada wanita usia 45 - 65 tahun menurut Angka Kecukupan Gizi (AKG). Pada penelitian ini, asupan karbohidrat tidak berhubungan dengan sindroma metabolik. Hal ini sesuai dengan penelitian observasional yang menunjukkan bahwa tidak terdapat hubungan asupan karbohidrat total dengan prevalensi sindroma metabolik. Hal ini disebabkan oleh kandungan indeks glikemik dalam asupan karbohidrat total tidak dijelaskan secara spesifik. ${ }^{39}$

Kelebihan penyimpanan karbohidrat dan kondisi oksidatif rentan mengalami resistensi insulin. Dalam kondisi isokalori, diet tinggi karbohidrat merangsang DNL (de novo lipogenesis) dalam meningkatkan kadar trigliserida plasma. Selain itu, terbentuk asam lemak dari sintesis VLDL. Malonil-coA merupakan substrat dalam sintesis asam lemak dan inhibitor karnitin palmitoil transferase. Kadar enzim terbatas dalam mentransfer asam lemak rantai panjang ke dalam mitokondria untuk oksidasi. Pengaruh langsung dan tidak langsung dari DNL yang tinggi berkontribusi terhadap produksi trigliserida dan menyebabkan hipertrigliseridemia. Asupan karbohidrat yang tinggi dapat memicu terjadinya hiperinsulinemia. Hormon insulin yang diproduksi secara berlebih dapat menyebabkan resistensi insulin dan peningkatan IMT serta obesitas sentral yang merupakan faktor risiko sindroma metabolik. ${ }^{40}$

Selain asupan isoflavon dan makronutrien, terdapat faktor lain yang dapat mempengaruhi sindroma metabolik yaitu aktivitas fisik. Rerata aktivitas fisik subyek pada kelompok sindroma metabolik yaitu 315,3 $\pm 190,2$ METs-min/minggu, sedangkan pada kelompok pra sindroma metabolik sebesar 456,6 $\pm 299,3$ METs-min/minggu. Sebanyak 43 subyek $(95,6 \%)$ dengan aktivitas fisik ringan mengalami sindroma metabolik. Suatu penelitian di Australia pada subyek dengan rata-rata umur 53,4 tahun menunjukkan, bahwa terdapat hubungan antara waktu dan intensitas aktivitas fisik dengan rata-rata lingkar pinggang dan indikator metabolik. Lingkar pinggang normal dan waktu serta intensitas aktivitas fisik berhubungan dengan rendahnya kadar trigliserida. ${ }^{41}$ Latihan fisik mempengaruhi kontrol glikemik, meningkatkan sensitivitas insulin dan toleransi glukosa serta menurunkan glikemia pada penderita diabetes. Aktivitas fisik meningkatkan kemampuan jaringan otot dalam pengeluaran asam lemak dan aktivitas enzim lipoprotein lipase dalam otot. Hal ini menunjukkan bahwa latihan fisik efektif dalam meningkatkan homeostasis lipid dan lipoprotein pada individu dengan sindroma metabolik. ${ }^{42,43}$ Pada penelitian ini, asupan makronutrien dan aktivitas fisik tidak terlalu membawa dampak yang berarti dikarenakan subyek penelitian hampir sebagian besar memiliki asupan makronutrien normal.

\section{SIMPULAN}

Rata-rata asupan isoflavon pada kelompok sindroma metabolik dan pra sindroma metabolik adalah 17,8 mg/hari dan $44 \mathrm{mg} /$ hari. Rerata asupan karbohidrat, protein, dan lemak pada kelompok sindroma metabolik lebih tinggi dibanding kelompok pra sindroma metabolik. Aktivitas fisik ringan lebih banyak pada kelompok sindroma metabolik $(95,6 \%)$ dibanding kelompok pra sindroma metabolik $(77,8 \%)$. Subyek dengan asupan isoflavon $<22 \mathrm{mg} / \mathrm{hr}$ ditemukan berisiko 6,8 kali lebih besar mengalami sindroma metabolik $(\mathrm{p}=0,000)$.

\section{SARAN}

Melakukan penyuluhan gizi pada kegiatan ibu-ibu, khususnya melalui posyandu lansia untuk memberikan pengetahuan gizi pada wanita menopause mengenai manfaat dan peran isoflavon. 
Di samping itu, perlu ditingkatkan aktivitas fisik pada wanita menopause secara teratur.

\section{DAFTAR PUSTAKA}

1. Kassi, Eva, Panagiota Pervanidou, Gregory Kaltas, and George Chrousos. Metabolic syndrome: definitions and controversies. BMC Medicine 2011, 9:48.

2. Liang, Huiying et al. The metabolic syndrome among postmenopausal women in rural canton: prevalence, associated factors, and the optimal obesity and the atherogenic indices. Plos one 2013, volume 8 , issue 9 .

3. K. Panchal, Sunil, Hemant Poudyal, and Lindsay Brown. Quercetin ameliorates cardiovascular, hepatic, and metabolic changes in diet-induced metabolic syndrome in rats. J. Nutr. 142: 1026 1032, 2012.

4. George M. Alberti, K. and Paul Z. Zimmet Metabolic syndrome: nomenclature, definition, and diagnosis. Dalam: Metabolic syndrome and cardiovascular disease: epidemiology, assessment, and management. New York: Informa Health Care USA, Inc; 2007.

5. Kamso, Sudijanto. Body mass index, total cholesterol, and ratio total to HDL cholesterol were determinants of metabolic syndrome in the Indonesian elderly. Med J Indones 2007; 16: 195200.

6. Jafar, Nurhaedar. Sindroma metabolik dan epidemiologi. Media Gizi Masyarakat Indonesia, Vol. 1, No.2, Februari 2012: 71-78.

7. Badan Penelitian dan Pengembangan Kesehatan. Riset Kesehatan Dasar 2013. Jakarta: Kementerian Kesehatan RI; 2013.

8. Dinas Kesehatan Kota Jepara. Buku Profil Kesehatan Kabupaten Jepara Tahun 2012. Jepara: Dinas Kesehatan Kota Jepara; 2012.

9. Dinas Kesehatan Provinsi Jawa Tengah. Buku Profil Kesehatan Provinsi Jawa Tengah Tahun 2012. Semarang: Dinas Kesehatan Provinsi Jawa Tengah; 2013.

10. P Tardivo, Ana et al. Associations between healthy eating patterns and indicators of metabolic risk in postmenopausal women. Nutrition Journal 2010, 9:64.

11. Nestel, Paul et al. Metabolic syndrome: recent prevalence in east and southeast Asian populations. Asia Pac J Clin Nutr 2007; 16(2): 362 - 367.

12. Goyal, Sapna, Mriganka Baruah, Runi Devi, and Kalpana Jain. Study on relation of metabolic syndrome with menopause. Ind J Clin Biochem (Jan-Mar 2013) 28(1): 55 - 60

13. Misra, Ranjita et al. Prevalence of diabetes, metabolic syndrome, and cardiovascular risk factors in US Asian Indians: result from a national study. Journal of Diabetes and Its Complications 24 (2010) $145-153$.

14. L Hall, Wendy et al. Soy-isoflavone-enriched foods and inflammatory biomarkers of cardiovascular disease risk in postmenopausal women: interactions with genotype and equol production. Am J Clin Nutr 2005; 82: 1260 - 8 .

15. Pilsakova, L., I. Riecansky, and F. Jagla. The physiological actions of isoflavone phytoestrogens. Physiol. Res. 59: 651 - 664, 2010.

16. E Geller, Stacie and Laura Studee. Botanical and Dietary Supplements for Menopause.

17. R Cena, Emily and Francene M. Steinberg. Soy may help protect against cardiovascular disease. California Agriculture: Vol. 65, No. 3; 2011.

18. Abete, Itziar, Arne Astrup, J Alfredo Martinez, Inga Thorsdottir, and Maria A Zulet. Obesity and the metabolic syndrome: role of different dietary macronutrient distribution patterns and specific nutritional components on weight loss and maintenance. Nutrition Review Vol. 68 (4): 214 231.

19. Nuzzo, Annachiara, Rosario Rossi, and Maria Grazia Modena. Hypertension alone or related to the metabolic syndrome in postmenopausal women. Expert Rev. Cardiovasc. Ther. 8(11), 1541 - 1548 (2010).

20. E. Alley, Dawn and Virginia W. Chang. Metabolic syndrome and weight gain in adulthood. J Gerontol A Biol Sci Med Sci; 2010 Vol. 65A, No. 1, 111 117.

21. Royer, M. et al. The US National Cholesterol Education Programme Adult Treatment Panel III (NCEP ATP III): prevalence of the metabolic syndrome in postmenopausal Latin American women. 2007, Vol. 10, No.2, Pages 164-170.

22. Batsis, JA, RE Nieto Martinez, and F Lopez Jimenez. Metabolic syndrome: from global epidemiology to individualized medicine. USA: Clinical Pharmacology and Therapeutics, Vol. 82 Number 5; 2007.

23. International Diabetes Federation. The IDF consensus worldwide definition of the metabolic syndrome. Belgium: International Diabetes Federation; 2006.

24. Food Safety Commission. Fundamental concepts in the safety assessment of foods containing soy isoflavones for the purpose of specified health use. Japan: Novel Foods Expert Committee; 2006.

25. Menteri Kesehatan Republik Indonesia. Peraturan Menteri Kesehatan Republik Indonesia Nomor 75 tahun 2013 tentang Angka Kecukupan Gizi yang Dianjurkan Bagi Bangsa Indonesia. 2013.

26. Bhagwat, Seema, David B. Haytowitz, and Joanne M. Holden. USDA Database for the Isoflavone Content of Selected Foods (Release 2). Beltsville: U.S. Department of Agriculture; 2008.

27. International Physical Activity Questionnaire. Short Last 7 Days Self-Administered version of IPAQ from the 2000/01 Reliability and Validity Study. 2001

28. Pan, An et al. Soy protein intake has sex-spesific effects on the risk of metabolic syndrome in middle- 
aged and elderly chinese. J. Nutr. 138: 2413 - 2421, 2008.

29. Jayagopal, Vijay et al. Beneficial effects of soy phytoestrogen intake in postmenopausal women with type 2 diabetes. Diabetes Care 25:1709 - 1714, 2002.

30. C. Filiberto, Amanda et al. Habitual dietary isoflavone intake is associated with decreased CReactive Protein concentrations among healthy premenopausal women. J.Nutr. 143: 900-906,2013.

31. Hyun Kim, Mi and Yun Jung Bae. Dietary isoflavone intake, urinary isoflavone level, and their relationship with metabolic syndrome diagnostic components in Korean postmenopausal women. Clin Nutr Res 2013; 2: 59 - 66.

32. Hodgson, Jonathan. Soy Protein and Isoflavones: Effects on Vascular Function and Blood Pressure in Human. Australia: Department of medicine; 2003.

33. Chan, Yap-Hang et al. Isoflavone intake in persons at high risk of cardiovascular events: implications for vascular endhotelial function and the carotid atherosclerotic burden. Am J Clin Nutr 2007;86:938 -45 .

34. Bhattamisra, S.K. et al. Effect of isoflavone rich soya seed extract on glucose utilization and endurance capacity in diabetic rat. Diabetologia Croatica 42-2, 2013.

35. T. Velasque, Manuel and Sam J. Bhathena. Role of Dietary Soy Protein in Obesity. International Journal of Medical Sciences, Volume 4, Number2, 2007.

36. Rebholz, CM et al. Effect of soybean protein on novel cardiovascular disease risk factors: a randomized controlled trial. European Journal of Clinical Nutrition (2013) 67, 58 - 63.

37. R. Hermann, Janice. Dietary fat and cholesterol. Division of Agricultural and Natural Resources: Oklahoma State University.

38. J. Appel, Lawrence et al. Effects of protein, monounsaturated fat, and carbohydrate intake on blood pressure and serum lipids: result of the Omniheart Randomized Trial. JAMA. 2005;294:2455-2464.

39. M. McKeown, Nicola et al. Carbohydrate nutrition, insulin resistance, and the prevalence of the metabolic syndrome in the Framingham Offspring Cohort. Diabetes Care 27:538 - 546, 2004.

40. S. Volek, Jeff et al. Dietary carbohydrate restriction induces a unique metabolic state positively affecting atherogenic dyslipidemia, fatty acid partitioning, and metabolic syndrome.

41. N. Healy, Genevieve et al. Objectively measured sedentary time, physical activity, and metabolic risk. Diabetes Care 31:369-371, 2008.

42. Ciolac, Emmanuel Gomes and Guilherme Veiga Guimaraes. Physical exercise and metabolic syndrome. Rev Bras Med Esporte - Vol. 10, No. 4 - Jul, 2004.

43. E. Robinson, Lindsay and Terry E. Graham. Metabolic syndrome, a cardiovascular disease risk factor: role of adipocytokines and impact of diet and physical activity. Can. J. Appl. Physiol. 29(6): 808829. 2004. 